\title{
Analysis on the Channel for China's Textile and Garment Enterprises to Implement the Environmental Strategies
}

\author{
Wang Shi ${ }^{1, *}$, \\ ${ }^{1}$ School of Fashion, Dalian Polytechnic University, Dalian, Liaoning 116034, China
}

\begin{abstract}
The textile and garment industry is a traditional industry in China, and the environmental issues like its sewage, wastes, noise and other problems arising therefrom are becoming increasing prominent while bring economic benefits, which causes concern as well. This paper sums up the channels for China's textile and garment enterprises to fulfill the environmental strategies by analyzing the disclosure of the environmental information from 75 sampling companies of the textile and garment enterprises in China from 2012 to 2014 on the basis of Guidance on Environmental Information Disclosure of Chinese Listed Company(Draft for Public Review) and the Measures for the Publicity of Environmental Information (for Trial Implementation) issued by the Ministry of Environmental Protection of the People's Republic of China.
\end{abstract}

\section{Introduction}

Sanjay Sharma and Harrie Vredenburg proposed forward-looking environmental strategies in 1998. They divided the environmental strategies into two categories, namely the reactive environmental strategy and proactive environmental strategy respectively. [1] Different enterprises holds different attitudes towards the environmental issues, and of course, they would select different environmental strategies. With the strengthening of public awareness on environmental protection and the reinforcement on the supervision of the enterprises' environmental activities by the government, more and more enterprises are starting to focus on their environmental activities and their environmental consequences, and they are also starting and enlarge the efforts they make on the disclosure of the environmental information in order to prove its effective implementation of environmental responsibility, establish and maintain its fine social image.

As a whole, the textile and garment enterprises have a low quality in environmental information disclosure, and the majority of companies simply describe the performance of its environmental responsibility qualitatively, with little quantitative information, and such information is only available from the notes to the statement. Most enterprises do not integrate the environmental strategies into its overall business strategy, and gain more profits at the costs of environmental pollution and environmental resource consumption through the traditional approaches of production and operation.

\section{Analysis on the Disclosures of Environmental Information by China's Textile and Garment Enterprises}

The indicator system for environmental information disclosure is established on the basis of Guidance on Environmental Information Disclosure of Chinese Listed Company (Draft for Public Review) and the Measures for the Publicity of Environmental Information (for Trial Implementation) as well as the actual situations of the environmental information disclosed by the textile and garment enterprises in China.[2]The disclosed information contains 6 aspects: 1. Information on Environmental Strategy; 2. Information on Environmental Resource Consumption and Emission Pollution; 3. Information on the Implementation of Environmental Strategy; 4. Information on Environmental Responsibility; 5. Adequate Disclosure of Environmental Information and Clarity; 6. The Independent Report, a total of 24 disclosure items of environmental information. As shown in (Table 1) the following table, the indicator range of 19 items is $(0-3)$, that of 4 items is $(0-2)$, that of one indicator is $(0-1)$, namely the range is $(0-66)$. The level of the environmental information disclosed by the sampling enterprises can be obtained by adding the scores for such information disclosure made by the textile and garment enterprises.

\footnotetext{
* Corresponding author: wangs85@126.com
} 
Table 1 Rating Criteria for Environmental Information Disclosure

\begin{tabular}{|c|c|c|}
\hline & Environmental Information Disclosure Items & Rating Criteria \\
\hline & Environmental Strategy Information & \\
\hline 1 & 1.1 Enterprise-related environmental regulations and policies & \multirow{5}{*}{$\begin{array}{c}\text { Failure to disclose: } 0 \text { point, } \\
\text { Qualitative disclosure: } 1 \text { point } \\
\text { Quantitative disclosure: } 2 \text { points; } \\
\text { Qualitative and quantitative } \\
\text { disclosure: } 3 \text { points }\end{array}$} \\
\hline 2 & 1.2 Operator's environmental philosophy and values & \\
\hline 3 & 1.3 Environmental measures and policies that are planned to take & \\
\hline 4 & 1.4 Objectives and plans for environmental protection and pollution control. & \\
\hline \multirow[t]{2}{*}{5} & 1.5 Global predication about the environmental conditions in the future & \\
\hline & $\begin{array}{l}\text { Information on Environmental Resource Consumption and Discharged } \\
\text { Pollutants }\end{array}$ & \\
\hline 6 & 2.1 Categories and number of the consumed natural resources & \multirow{2}{*}{$\begin{array}{c}\text { Failure to disclose: } 0 \text { point, } \\
\text { Qualitative disclosure: } 1 \text { point } \\
\text { Quantitative disclosure: } 2 \text { points; } \\
\text { Qualitative and quantitative } \\
\text { disclosure: } 3 \text { points }\end{array}$} \\
\hline 7 & 2.2 Categories and number of the discharged pollutants & \\
\hline 8 & 2.3 Whereabouts of the discharged pollutants & \multirow{2}{*}{$\begin{array}{c}\text { Failure to disclose: } 0 \text { point; Simply } \\
\text { disclosure: } 1 \text { point } \\
\text { Detailed disclosure: } 2 \text { points }\end{array}$} \\
\hline \multirow[t]{2}{*}{9} & 2.4 Whether the pollutant emission meets the standards & \\
\hline & Information on the Implementation of the Environmental Protection & \\
\hline 10 & $\begin{array}{l}\text { 3.1 Investment of the Enterprises in environmental governance (including } \\
\text { greening) }\end{array}$ & \multirow{8}{*}{$\begin{array}{l}\text { Failure to disclose: } 0 \text { point, } \\
\text { Qualitative disclosure: } 1 \text { point } \\
\text { Quantitative disclosure: } 2 \text { points; } \\
\text { Qualitative and quantitative } \\
\text { disclosure: } 3 \text { points }\end{array}$} \\
\hline 11 & $\begin{array}{l}\text { 3.2 Treatment and disposal of the wastes generated by the enterprise during } \\
\text { the production }\end{array}$ & \\
\hline 12 & $\begin{array}{l}\text { 3.3 Information on energy conservation and emission reduction as well as } \\
\text { cleaner production; waste recovery and utilization and energy conservation }\end{array}$ & \\
\hline 13 & 3.4 Government subsidies, incentives, tax reduction and exemption & \\
\hline 14 & 3.5 Other environmental control measures and matters & \\
\hline 15 & 3.6 Disclosure of environmental technology and facilities & \\
\hline 16 & 3.7 Scientific research and development & \\
\hline 17 & 3.8 Environmental assessment on the project construction & \\
\hline \multirow[t]{2}{*}{18} & 3.9 Information on whether passing the environmental quality certification & Yes: 2 points; No: 0 point \\
\hline & Information on environmental responsibility & \\
\hline 19 & $\begin{array}{l}\text { 4.1 Obligation, responsibility or litigation that may bear due to the } \\
\text { environmental problem }\end{array}$ & \multirow{4}{*}{$\begin{array}{l}\text { Failure to disclose: } 0 \text { point, } \\
\text { Qualitative disclosure: } 1 \text { point } \\
\text { Quantitative disclosure: } 2 \text { points; } \\
\text { Qualitative and quantitative } \\
\text { disclosure: } 3 \text { points }\end{array}$} \\
\hline 20 & $\begin{array}{c}4.2 \text { Impact of the products made by or other productive activities conducted } \\
\text { by the enterprises on the environment }\end{array}$ & \\
\hline 21 & 4.3 Costs and losses borne due to the environment pollution & \\
\hline 22 & $\begin{array}{l}\text { 4.4 Impact of the environmental Issues on the financial status of the } \\
\text { enterprise }\end{array}$ & \\
\hline 23 & Centralize the Environmental Information Disclosure into Paragraphs & $\begin{array}{c}1 \text { points if the environmental } \\
\text { information is centralized into } \\
\text { paragraphs for disclosure; otherwise, } \\
0 \text { points. }\end{array}$ \\
\hline 24 & $\begin{array}{c}\text { Independent Environmental Report, Social Responsibility Report, } \\
\text { Sustainability Report or Environmental Report }\end{array}$ & $\begin{array}{l}\text { The independent environmental } \\
\text { report: } 2 \text { points; otherwise, } 0 \text { point }\end{array}$ \\
\hline
\end{tabular}

The score for the disclosure level of the environmental information is divided into 7 sections, recording the score distributions for the 225 samples from the 75 listed companies in the textile and garment industry in recent 3 years, as shown in Figure 1. There were 167 enterprises getting 0-10 points in 3 years from 2012 to 2014, 41 enterprises getting 10-20 points, 14 enterprises getting 20-30 points and 1 enterprise getting $30-40$ points, 2 enterprises getting 50-60 points, and no enterprise getting 40-50 points as well as $60-66$ points. Under the premise of 66 points in total, $74.22 \%$ of the enterprises got the scores of less than 10 points, and it can be seen from Figure 1 that, the vast majority of the enterprises did not attach importance to environmental issues, but fulfilled their environmental responsibilities passively, and these enterprises lacked the initiative for environmental management, and implemented the reactive environmental strategy. 


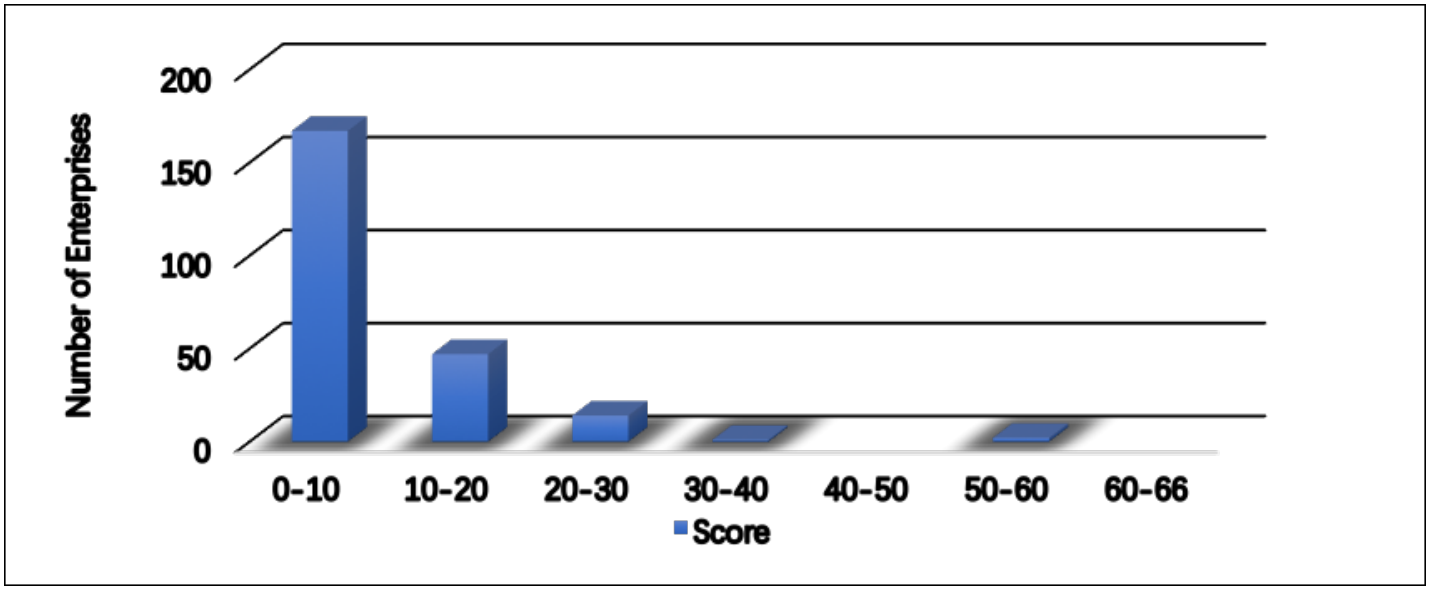

Fig. 1. Enterprise Score Distribution Diagram.

It could be seen from the average value for the environmental information disclosure, their score was no more than 10 points from 2012-2014, among which the score in 2014 was the lowest, and the average score obtained by the enterprises only accounted for about $10 \%$ of the total scores, indicating that the majority of the enterprises did not implement the proactive environmental strategies. See Table 2 for more information:

Table 2 Rating Criteria for Environmental Information Disclosure for the Desired Situation in 2012-2014

\begin{tabular}{|c|c|c|c|}
\hline Year & $\mathbf{2 0 1 2}$ & $\mathbf{2 0 1 3}$ & $\mathbf{2 0 1 4}$ \\
\hline $\begin{array}{c}\text { Average Score for } \\
\text { Environmental } \\
\text { Information Disclosure }\end{array}$ & 7.87 & 7.96 & 6.97 \\
\hline $\begin{array}{c}\text { Percentage Accounting } \\
\text { for the Desired } \\
\text { Situation(\%) }\end{array}$ & 11.92 & 12.06 & 10.56 \\
\hline
\end{tabular}

The status quo for implementing the environmental strategies by the enterprises can be summed up roughly by analyzing the scores obtained by the textile and garment enterprises for the disclosure of the environmental information as well as the mode of disclosure. Based on the above criteria, the 75 textile and garment enterprises were scored according to the environmental information disclosed in the annual report of 2012-2014 and the independent report. Table 3 makes a summary, indicating the number of the enterprises implementing the corresponding environmental strategies, scores and percentage of the enterprises of the environmental responsibility accounting for the total enterprises. As shown in Table 3:

\subsection{Disclosure Related to Environmental Strategy Information}

The disclosed environmental strategy information contains the enterprise-related environmental regulations and policies, the operator's environmental philosophy and values, the environmental measures and policies that are planned to take, the objectives and plans for environmental protection and pollution control as well as the global predication about the environmental conditions in the future. The enterprises disclosing the environmental strategy information are less than half. Under the premise that the qualitative disclosure is awarded with 1 point, the quantitative disclosure is awarded with 2 points and the qualitative and quantitative disclosure will be awarded with 3 points as the rating criteria, the number of the enterprises disclosing the information is close to the score, indicating that the disclosing enterprises make qualitative description, and there are few textile and garment enterprises that own environmental philosophy and values and make plans for the environmental issues during the operations.

\subsection{Disclosure Related to Information on Environmental Resource Consumption and Discharged Pollutants}

There are only about 10 enterprises disclosing the "categories and number of the consumed natural resources as well as the types, quantity and content of the discharged pollutants", and there are only 2 or 3 enterprises disclosing the whereabouts of the pollutants. It is indicated that the enterprises do not attach importance to the consumption of the natural resources, and do not "conserve the energy"; they seldom disclose the whereabouts of the pollutants and the wastes, or do not attach importance to the impact of the pollutants on the environment, and do not "reduce the emissions".

\subsection{Disclosure Related to Information on Implementation of Environmental Strategy}

It can be seen from the disclosure that there are only 10 enterprises making investment in environmental governance and training the employees on environmental protection in recent 3 years, and only 35 enterprises conduct energy conservation and emission reduction as 
Table 3 Number and Scores of the Enterprises for the Disclosure of the Environmental Information from 2012 to 2014

\begin{tabular}{|c|c|c|c|c|c|c|c|c|c|c|}
\hline & \multirow{2}{*}{$\begin{array}{c}\text { Environmental } \\
\text { Information } \\
\text { Disclosure } \\
\text { Items }\end{array}$} & \multicolumn{3}{|c|}{2012} & \multicolumn{3}{|c|}{2013} & \multicolumn{3}{|c|}{2014} \\
\hline & & No*. & $\% *$ & $\underset{*}{\text { Score }}$ & No. & $\%$ & Score & No. & $\%$ & Score \\
\hline & \multicolumn{10}{|c|}{ Environmental Strategy Information } \\
\hline 1 & 1.1 & 36 & 46.75 & 38 & 37 & 48.05 & 41 & 34 & 44.16 & 34 \\
\hline 2 & 1.2 & 34 & 44.16 & 36 & 38 & 49.35 & 40 & 39 & 50.65 & 39 \\
\hline 3 & 1.3 & 29 & 37.66 & 33 & 32 & 40.26 & 35 & 28 & 36.36 & 28 \\
\hline 4 & 1.4 & 22 & 28.57 & 26 & 23 & 29.87 & 25 & 21 & 27.27 & 23 \\
\hline 5 & 1.5 & 20 & 25.97 & 22 & 18 & 23.38 & 20 & 16 & 20.78 & 16 \\
\hline & \multicolumn{10}{|c|}{ Information on Environmental Resource Consumption and Discharged Pollutants } \\
\hline 6 & 2.1 & 9 & 11.69 & 15 & 12 & 15.58 & 16 & 8 & 10.39 & 10 \\
\hline 7 & 2.2 & 10 & 12.99 & 18 & 8 & 10.39 & 14 & 7 & 9.09 & 13 \\
\hline 8 & 2.3 & 3 & 3.90 & 4 & 2 & 2.60 & 3 & 2 & 2.60 & 3 \\
\hline 9 & 2.4 & 21 & 27.27 & 25 & 22 & 28.57 & 27 & 18 & 23.38 & 20 \\
\hline & \multicolumn{10}{|c|}{ Information on the Implementation of the Environmental Protection } \\
\hline 10 & 3.1 & 11 & 14.29 & 19 & 12 & 15.58 & 23 & 9 & 11.69 & 14 \\
\hline 11 & 3.2 & 17 & 22.08 & 24 & 13 & 16.88 & 19 & 13 & 16.88 & 19 \\
\hline 12 & 3.3 & 33 & 42.86 & 55 & 36 & 46.75 & 58 & 34 & 44.16 & 48 \\
\hline 13 & 3.4 & 32 & 41.56 & 65 & 33 & 42.86 & 65 & 42 & 54.55 & 64 \\
\hline 14 & 3.5 & 11 & 14.29 & 13 & 13 & 16.88 & 15 & 9 & 11.69 & 9 \\
\hline 15 & 3.6 & 24 & 31.17 & 34 & 29 & 37.66 & 41 & 30 & 38.96 & 46 \\
\hline 16 & 3.7 & 18 & 23.38 & 30 & 17 & 22.8 & 30 & 18 & 23.38 & 27 \\
\hline 17 & 3.8 & 8 & 10.39 & 12 & 7 & 9.09 & 11 & 4 & 5.19 & 6 \\
\hline 18 & 3.9 & 28 & 36.36 & 56 & 28 & 36.36 & 54 & 27 & 35.06 & 54 \\
\hline & \multicolumn{10}{|c|}{ Information on environmental responsibility } \\
\hline 19 & 4.1 & - & - & - & - & - & - & - & - & - \\
\hline 20 & 4.2 & 1 & 1.3 & 2 & 1 & 1.30 & 2 & - & - & - \\
\hline 21 & 4.3 & 3 & 3.9 & 8 & 2 & 2.60 & 5 & 1 & 1.3 & 2 \\
\hline 22 & 4.4 & - & - & - & - & - & - & - & - & - \\
\hline 23 & $\begin{array}{l}\text { Centralize the } \\
\text { Environmental } \\
\text { Information } \\
\text { Disclosure into } \\
\text { Paragraphs }\end{array}$ & 21 & 27.27 & 41 & 19 & 24.68 & 37 & 20 & 25.79 & 39 \\
\hline 24 & $\begin{array}{c}\text { Independent } \\
\text { Environmental } \\
\text { Report, Social } \\
\text { Responsibility } \\
\text { Report, } \\
\text { Sustainability } \\
\text { Report or } \\
\text { Environmental } \\
\text { Report }\end{array}$ & 17 & 22.08 & 34 & 17 & 22.08 & 34 & 14 & 18.18 & 28 \\
\hline
\end{tabular}

Note : No* refers to Number of Enterprises

* refers to Percentage of Disclosing Enterprises Score* refers to Project Score 
well as cleaner production. There are only 18 technical research and development enterprises, and 25 enterprises owning environmental protection technology and facilities. The implementation measures for environment protection are the important elements for implementing the proactive environmental strategies, but there are only 30 out of 75 enterprises implementing the measures for environmental protection.

\subsection{Disclosure Related to Information on Environmental Legal Liability}

In general, the disclosed contents of the environmental liability assumed due to the violation of the environmental laws and regulations shall include the obligations, liabilities or litigations that shall be borne arising from the environmental issues, the impact of the products made by or other productive process conducted by the enterprises on the environment, the cost loss assumed due to the environmental pollution, like the sewage charges and governance fees, the environmental damage compensation paid to the state, and the impact of the environmental issues on the financial status of the enterprise. The environmental liability that shall be assumed due to the violation of environmental laws and regulations is often the consequences for nonimplementation of the proactive environmental strategies, and there are only no more than 5 enterprises disclosing the environmental liability. The causes for such few enterprises disclosing the information are that the enterprises won't disclose the enterprise-related negative environmental information in order to maintain its fine social image.

\section{Conclusion}

Currently, the textile and garment industry in China still takes a fancy to short-term economic benefits, and gains economic growth at the costs of consuming the environmental resources and endangering the ecological environment by analyzing the status quo of the disclosure mode of the environmental information by and the scores obtained by the textile and garment enterprises, in combination of the proactive environmental strategies performed by the enterprises. Such situation is badly in need of changes, and the economic growth mode shall be transformed so as to realize the sustainable development of the economy and the environment.

\section{References}

1. Zhang Teng. Proactive Environmental Strategy The Environmental Strategy that Shall be Taken by the Large-scale State-owned Enterprises[J]Market Modernization, 2012(32):91-92.

2. Fang Xiaojuan. Study on the Disclosure Level of Environmental Information, Environmental Performance and Financial Performance of the
Listed Companies from Manufacturing Industry[D]. Anhui University, 2013 